\title{
Identification of a 16SrII-E Phytoplasma in Calendula arvensis, Solanum nigrum, and Chenopodium spp.
}

\author{
G. Tolu, Dipartimento di Protezione delle Piante-sezione di Patologia vegetale, Università degli Studi, via De Nicola 1, \\ 07100 Sassari, Italy; S. Botti, DiSTA, Patologia vegetale, Alma Mater Studiorum, Università di Bologna, viale Fanin, \\ 42, 40127 Bologna, Italy; R. Garau, V. A. Prota, A. Sechi, and U. Prota, Dipartimento di Protezione delle Piante- \\ sezione di Patologia vegetale, Università degli Studi, via De Nicola 1, 07100 Sassari, Italy; and A. Bertaccini, DiSTA, \\ Patologia vegetale, Alma Mater Studiorum, Università di Bologna, viale Fanin, 42, 40127 Bologna, Italy
}

\begin{abstract}
Tolu, G., Botti, S., Garau, R., Prota, V. A., Sechi, A., Prota, U., and Bertaccini, A. 2006. Identification of a 16SrII-E phytoplasma in Calendula arvensis, Solanum nigrum, and Chenopodium spp. Plant Dis. 90:325-330.

Epidemiological surveys were performed in Northern Sardinia (Italy) in a 10-year-old vineyard affected by "Bois noir" disease. Samples collected between May and October 2003 from chlorotic and stunted weeds belonging to 14 different taxonomic groups were indexed molecularly for detection of phytoplasmas. Nested polymerase chain reaction (PCR) assays using primers specific for the phytoplasma 16SrDNA gene showed three of six Calendula arvensis, one of two Solanum nigrum, and one of seven Chenopodium spp. assayed positive. Restriction fragment length polymorphism analyses and sequencing of amplified 16SrDNA fragments identified a putative phytoplasma in the ribosomal subgroup 16SrII-E. Further characterization of the rps 3 gene, coding a ribosomal protein, confirmed the identification. However, the weeds and leafhopper species collected in the vineyard tested negative by PCR assays for the Stolbur phytoplasma, the causal agent of "Bois noir". This is the first report of a phytoplasma of the 16SrII-E subgroup infecting $C$. arvensis, S. nigrum, and Chenopodium spp.
\end{abstract}

Phytoplasmas, prokaryotes with phloematic habitats, are found throughout the world on wild and cultivated plants (25); they belong to the class Mollicutes and are taxonomically distinguished by molecular characteristics, especially on $16 \mathrm{~S}$ ribosomal genes, established principally by polymerase chain reaction (PCR), restriction fragment length polymorphism (RFLP), and phylogenetic comparisons (17). Phytoplasma infections cause symptoms on the plant which are often nonspecific and not associated with a particular phytoplasma taxonomic group. Frequent symptoms caused by phytoplasmas are yellowing, discoloration, witches'-broom, dwarfing, virescence, and phyllody. In nature, phytoplasmas are transmitted by leafhoppers (Auchenorrhyncha). These insects may have an occasional or a permanent and essential trophic relationship with their hosts. Scaphoideus titanus Ball, for example, is an essential ampelophaga, i.e., it feeds only on grape, whereas Euscelis lineolatus Brullè, Laodelphax striatellus Fallèn, and others are well known to be dependent on herba-

Corresponding author: A. Bertaccini

E-mail: Bertaccini_a@biblio.cib.unibo.it

Accepted for publication 19 October 2005.

DOI: 10.1094/PD-90-0325

(C) 2006 The American Phytopathological Society ceous species and may only occasionally be ampelophaga.

On Vitis vinifera, the phytoplasmas cause a syndrome called "yellows", found in Europe and in grape-growing areas outside Europe. Yellows is mainly characterized by yellow leaves, yellow periveinal bands, leaf curling, and lack of cane lignification. These symptoms are found in both "Flavescence dorée" and "Bois noir" diseases. In "Flavescence dorée", the symptoms are caused by phytoplasmas that belong to the $16 \mathrm{SrV}$ group (Elm yellows), transmitted by the cicadellid $S$. titanus. In "Bois noir" disease, symptoms are caused by phytoplasmas of the 16SrXII-A subgroup transmitted by the cixid Hyalesthes obsoletus Signoret. Although this phytoplasma has frequently been found in the herbaceous flora of vineyards and in various species of insects $(15,16,20)$, the epidemiological relationship between the host and the vector is not completely clarified.

Grapevine yellows is widespread in different viticultural areas of Sardinia (Italy). Based on recent studies, symptomatic plants are infected by the Stolbur phytoplasma belonging to the 16SrXII-A subgroup, inducing the "Bois noir" disease on grapevines (6). The leafhopper Goniagnathus guttulinervis (Kirschbaum) is a natural host of this phytoplasma; however, its role as a vector has not yet been established (5). Although the presence of this phytoplasma in weeds and in different leafhopper species has been repeatedly reported, there are cases in which the epidemiology of grapevine yellows and its relationship with possible vectors has not been established. In Sardinia, for example, outbreaks of "Bois noir" have occurred in an apparent absence of the vector $H$. obsoletus. Thus, a study was undertaken to assess the presence of Stolbur phytoplasmas in weeds and insects in a vineyard affected by "Bois noir".

\section{MATERIALS AND METHODS}

Field survey. Weed samples were collected from May to October 2003 among the most common species growing within a Chardonnay vineyard of northern Sardinia, and analyzed for phytoplasma presence using molecular techniques. Seventyeight samples were tested: Lolium spp. (6 plants), Convolvulus arvensis L. (7), Chenopodium spp. (7), Trifolium repens $\mathrm{L}$. (6), Malva silvestris L. (5), Calendula arvensis L. (6), Erigeron canadensis L. (6), Helmintia echioides Gaertn. (5), Plantago lanceolata L. (5), Amaranthus spp. (6), Solanum nigrum L. (2), Bromus sterilis L. (6), Avena fatua L. (6), and Hordeum murinum Huds. (5). Most plants showed apical yellowing, while $C$. arvensis plants were stunted.

Preliminary studies to determine the presence of Auchenorrhyncha on the weeds of the vineyard were carried out monthly from May to August 2003. Standard entomological nets were used to collect the samples; the insects were collected from $150 \mathrm{~m}$ of the vineyard in all, and from four rows. The captured insects were classified, preserved in $\mathrm{a}-20^{\circ} \mathrm{C}$ freezer for a week, and then examined molecularly. The tests were carried out as described below on 14 samples, in batches ranging from 5 to 15 individuals, according to the size of the species.

PCR and RFLP on 16SrDNA and $r p S 3$ gene sequences. Nucleic acid extraction for PCR analyses was performed on weed and insect samples using the Doyle and Doyle system (4). The DNA was stored in TE at $-20^{\circ} \mathrm{C}$. A direct PCR was carried out with universal primers $\mathrm{R} 16 \mathrm{~F} 2 / \mathrm{R} 2$ (9). A touch-down procedure was used, consisting of heating at $95^{\circ} \mathrm{C}$ for $5 \mathrm{~min}$, at $58^{\circ} \mathrm{C}$ for $1.5 \mathrm{~min}$, followed by a one degree decrease with eight 1.5 -min cycles to $50^{\circ} \mathrm{C}$, and a final extension step 
Table 1. Phytoplasma 16SrDNA sequences retrieved from GenBank, including AJ744767 - Calendula stunt from Sardinia - and employed for phylogenetic analysis

\begin{tabular}{|c|c|c|c|c|}
\hline Accession no. & Phytoplasma strain & Abbreviation & Origin & $\begin{array}{l}\text { 16SrRNA } \\
\text { group }^{a}\end{array}$ \\
\hline AF438413 & Alfalfa witches'-broom & OmanAlfWB & Oman & 16SrII-D \\
\hline AF248958 & Apple proliferation & $\mathrm{AP}$ & Italy & $16 \mathrm{SrX}-\mathrm{A}$ \\
\hline AF189215 & Ash yellows & ASHY & New York & 16SrVII-A \\
\hline AF222063 & Aster yellows & AY & Maryland & 16SrI-B \\
\hline AF248961 & Bermuda grass white leaf & BGWL & Thailand & 16SrIV-A \\
\hline AF228052 & Brinjal little leaf & BLL & India & n.a. \\
\hline AF200718 & Cactus & Cactus & Mexico & n.a. \\
\hline AJ744767 & Calendula stunting & Calendula stunt & Italy & $16 \mathrm{SrII}-\mathrm{E}$ \\
\hline AF515637 & $\begin{array}{l}\text { "Candidatus Phytoplasma } \\
\text { phoenicium" }\end{array}$ & $\mathrm{CP}$ & Lebanon & $16 \mathrm{SrIX}$ \\
\hline AF495882 & Chinaberry yellows & $\mathrm{CbY}$ & Bolivia & $16 \mathrm{SrXIII}$ \\
\hline AF028813 & $\begin{array}{l}\text { Chinese pigeon pea } \\
\text { witches'-broom }\end{array}$ & CPPW & Taiwan & $16 \mathrm{SrII}$ \\
\hline AF173558 & Clover yellow edge & CYE & Canada & 16SrIII-B \\
\hline AY101386 & Epilobium phyllody & $\mathrm{EP}$ & Estonia & $16 \mathrm{SrI}$ \\
\hline AF411592 & Erigeron witches'-broom & EWB & Brazil & 16SrVII \\
\hline AY029540 & $\begin{array}{l}\text { European stone fruit yellows } \\
\text { from apricot }\end{array}$ & ESFY & Austria & $16 \mathrm{SrX}-\mathrm{B}$ \\
\hline X83432 & Faba bean phyllody & FBP & Sudan & $16 \mathrm{SrII}-\mathrm{C}$ \\
\hline AB026155 & Gerbera phyllody & GP & Japan & $16 \mathrm{SrII}-\mathrm{C}$ \\
\hline Y16390 & Italian alfalfa witches'-broom & ItalAWB & Italy & n.a. \\
\hline AF305240 & Jujube witches'-broom & JJWB & China & $16 \mathrm{SrV}-\mathrm{B}$ \\
\hline Y18053 & Knautia phyllody & $\mathrm{KP}$ & Italy & n.a. \\
\hline AF515638 & Lactuca serriola phyllody & LsP & Lebanon & 16SrIX \\
\hline $\mathrm{U} 15442$ & Lime witches'-broom & LWB & Oman & 16SrII-B \\
\hline AF248956 & Loofah witches'-broom & LfWB & Taiwan & 16SrVIII-A \\
\hline AF248960 & Mexican periwinkle virescence & MPV & Mexico & 16SrXIII-A \\
\hline Y10097 & Papaya yellow crinkle & PapayaYC & Australia & n.a. \\
\hline AF228053 & Periwinkle little leaf & PerLL & Bangladesh & n.a. \\
\hline Y15866 & Phytoplasma sp. Strain Vill & ViLL & Australia & n.a. \\
\hline Y16393 & Picris echioides phyllody & PEP & Italy & 16SrII-E \\
\hline Y16389 & Picris echioides yellows & PEY & Italy & $16 \operatorname{SrIX}$ \\
\hline AJ310849 & Pine phytoplasma & Pine & Germany & n.a. \\
\hline U89378 & Rape phyllody & $\mathrm{RP}$ & Czech Rep. & n.a. \\
\hline Y16395 & Rubus stunt & RuS & Italy & $16 \mathrm{SrV}-\mathrm{E}$ \\
\hline AJ289192 & Stilosantes little leaf & StiLL & Australia & n.a. \\
\hline AF248959 & Stolbur & STOL & Serbia & 16SrXII-A \\
\hline AJ243044 & Strawberry green petals & AustrSG & Australia & 16SrXII-B \\
\hline AF056095 & Sugarcane yellows & SCY & South Africa & n.a. \\
\hline AF222064 & Tomato big bud & TomBB & Arkansas & 16SrI-B \\
\hline AF521672 & $\begin{array}{l}\text { Weeping tea tree } \\
\text { witches'-broom }\end{array}$ & WttWB & Australia & n.a. \\
\hline
\end{tabular}

a n.a. = group not available.
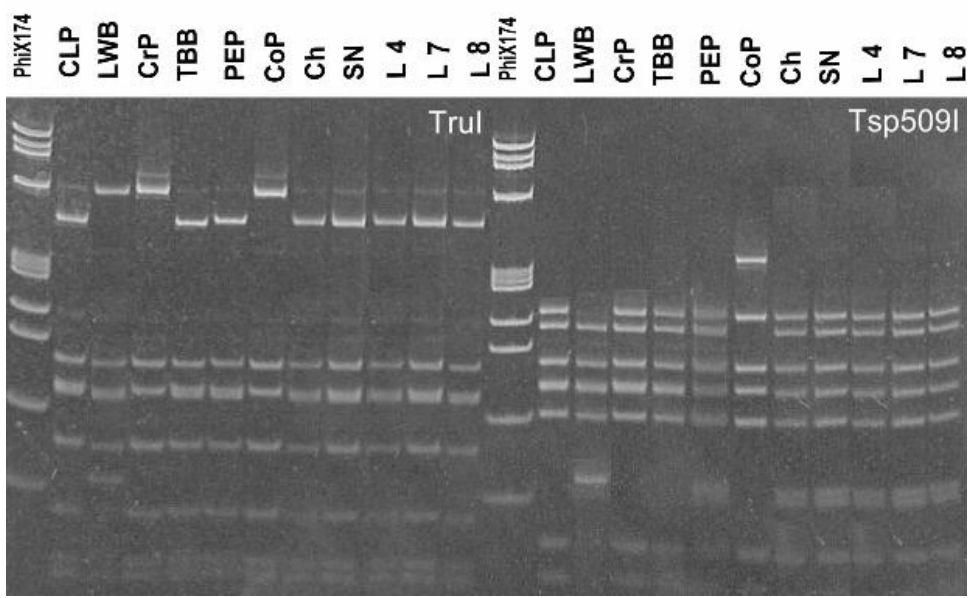

Fig. 1. Polyacrylamide gel showing restriction fragment length polymorphism patterns of $16 \mathrm{SrDNA}$ amplified with primer pair R16(I)F1/R1 from weed samples of Chenopodium spp. (Ch), Solanum nigrum (SN), and Calendula arvensis (L4, L7, and L8) and selected reference phytoplasma strains digested with restriction enzymes TruI and Tsp509I. CLP, cleome phyllody (16SrII-A); LWB, Lime witches'-broom (16SrII-B); CrP, crotalaria phyllody (16SrII-C); TBB, tomato big bud from Australia (16SrII-D); PEP, Pichris echioides phyllody (16SrII-E); CoP, cotton phyllody (16SrII-F). P, ФX174, marker HaeIII digested; fragment sizes in base pairs from top to bottom: 1,353, 1,078, 872, 603, 310, $281,271,234,194,118$, and 72 . at $72^{\circ} \mathrm{C}$ for $1.2 \mathrm{~min}$. Then PCR continued for 25 cycles at $95^{\circ} \mathrm{C}$ for $1 \mathrm{~min}, 50^{\circ} \mathrm{C}$ for $1.30 \mathrm{~min}$, and $72^{\circ} \mathrm{C}$ for 1.2 min with a final step at $72^{\circ} \mathrm{C}$ for $5 \mathrm{~min}$. Amplification was done with a Thermocycler (Hybaid, Middlesex United Kingdom, EU) in 50- $\mu$ l reactions containing $1 \times$ PCR buffer, $2 \mathrm{mM}$ $\mathrm{MgCl}_{2}, 200 \mu \mathrm{M}$ of each dNTP (Invitrogen, Carlsbad, CA, USA), R16F2/R2 $100 \mathrm{nM}$, and $1 \mathrm{U}$ of Red Taq (Sigma-Aldrich, St. Louis, MO, USA).

Two microliters of diluted (1:50) PCR products from the first amplification were employed as templates for nested PCR using the primer pair R16(I)F1/R1 (18). Thirty-five PCR cycles were run with the following parameters: $1 \mathrm{~min}(3 \mathrm{~min}$ for the first cycle) at $94^{\circ} \mathrm{C}, 1 \mathrm{~min}$ at $50^{\circ} \mathrm{C}$, and 75 $\mathrm{s}\left(5 \mathrm{~min}\right.$ in final cycle) at $72^{\circ} \mathrm{C}$. The $50-\mu \mathrm{l}$ reaction mix contained $1 \times$ PCR buffer, 2 $\mathrm{mM} \mathrm{MgCl} 2,200 \mu \mathrm{M}$ of each dNTP, $1 \mu \mathrm{M}$ R16(I)F1/R1, and $1 \mathrm{U}$ of Red Taq. Amplified DNA was separated by electrophoresis in $1.2 \%$ agarose gels stained with ethidium bromide; the bands were visualized with a Gel-Doc 2000 Documentation System (Bio-Rad Laboratories, Milan, Italy, EU).

Nucleic acid from the positive samples and from the reference samples in periwinkle (Catharanthus roseus): CLP, cleome phyllody (16SrII-A); CrP, crotalaria phyllody (16SrII-C); TBB, tomato big bud from Australia (16SrII-D); PEP, Pichris echioides phyllody (16SrII-E); CoP, cotton phyllody (16SrII-F), as well as from lime witches'-broom phytoplasma (16SrII-B) obtained from lime (Citrus aurantiaca) (12), which represented different ribosomal subgroups in ribosomal group 16SrII (12), was amplified again using primers P1/P7 $(3,26)$ followed by nested PCR as described above with the primer pair R16F2/R2. The amplicons were obtained in a total volume of $25 \mu \mathrm{l}$ PCR mixture containing $2.5 \mu \mathrm{l}$ of $10 \times$ PCR buffer, $200 \mu \mathrm{M}$ of each dNTP, $0.4 \mu \mathrm{M}$ of each primer, and $0.625 \mathrm{U}$ of $\mathrm{Taq}$ polymerase (Polymed, Florence, Italy, EU). Samples lacking DNA were run as negative controls. After amplification, 5- $\mu$ l aliquots from each sample were separated by electrophoresis in a $2 \%$ agarose gel, stained with ethidium bromide, and visualized using Gel-Doc.

Two hundred to $300 \mathrm{ng}$ of R16(I)F1/R1 amplicons were then subjected to RFLP analysis using TruI and Tsp509I (Fermentas, Vilnius, Lithuania, EU) following the manufacturer's instructions. Further RFLP analyses were carried out on R16F2/R2 nested PCR products with TruI, Tsp509I, and DdeI (Fermentas). The restriction patterns were compared after electrophoresis in a 5\% polyacrylamide gel and staining of the products with ethidium bromide.

Under similar conditions, further amplifications for molecular characterization of phytoplasmas were performed on the S3 ribosomal protein of the $C$. arvensis L4 sample using semi-nested PCR primers 


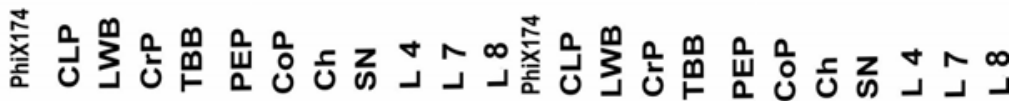

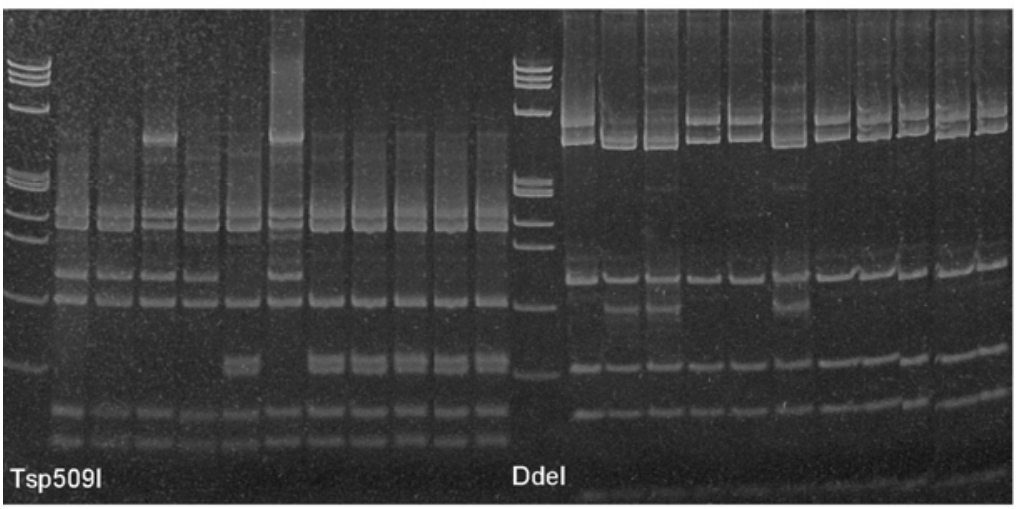

Fig 2. Polyacrylamide gel showing restriction fragment length polymorphism patterns of reference phytoplasma strains and strains from weed samples amplified with phytoplasma-specific primers R16F2/R2 and digested with restriction enzymes Tsp509I and DdeI. CLP, cleome phyllody (16SrII-A); LWB, Lime witches'-broom (16SrII-B); CrP, crotalaria phyllody (16SrII-C); TBB, tomato big bud from Australia (16SrII-D); PEP, Pichris echioides phyllody (16SrII-E); CoP, cotton phyllody (16SrIIF). P, $\Phi$ X174, marker HaeIII digested; fragment sizes in base pairs from top to bottom: 1,353, 1,078, $872,603,310,281,271,234,194,118$, and 72.

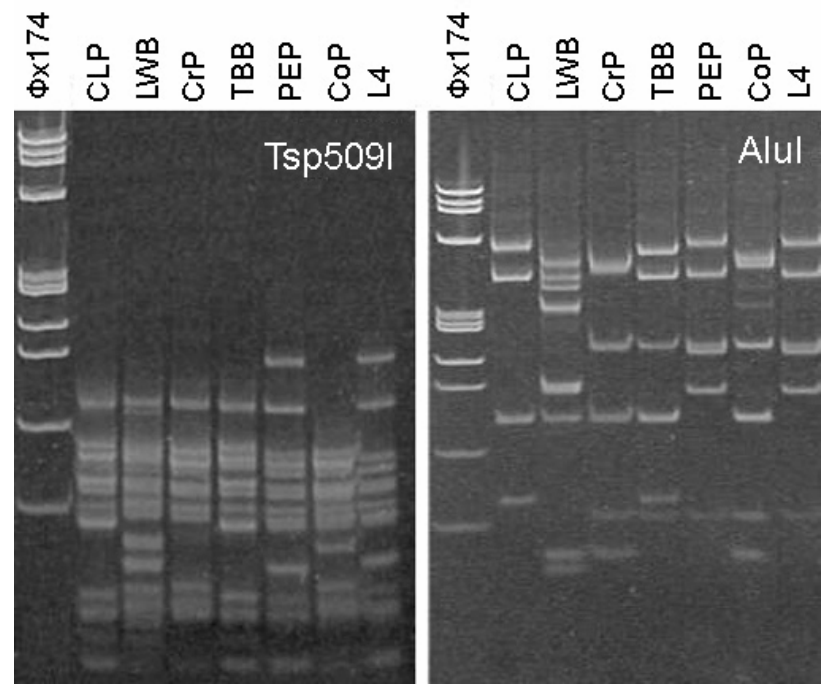

Fig. 3. Polyacrylamide gels showing the restriction fragment length polymorphism of reference phytoplasma samples and sample L4 amplified with primers $\mathrm{rp}(\mathrm{II}) \mathrm{F} 1 / \mathrm{rp}(\mathrm{I}) \mathrm{R} 1 \mathrm{~A}$ followed by primers $\mathrm{rp}(\mathrm{II}) \mathrm{F} 2 / \mathrm{rp}(\mathrm{I}) \mathrm{R} 1 \mathrm{~A}$ in seminested polymerase chain reaction (PCR) and digested with restriction enzymes Tsp509I and AluI. CLP, cleome phyllody (16SrII-A); LWB, Lime witches'-broom (16SrII-B); CrP, crotalaria phyllody (16SrII-C); TBB, tomato big bud from Australia (16SrII-D); PEP, Pichris echioides phyllody (16SrII-E); CoP, cotton phyllody (16SrII-F). P, ФX174, marker HaeIII digested; fragment sizes in base pairs from top to bottom: 1,353, 1,078, 872, 603, 310, 281, 271, 234, 194, 118, and 72 . specific for ribosomal group $16 \mathrm{SrII}$ : $\mathrm{rp}(\mathrm{II}) \mathrm{F} 1 / \mathrm{rp}(\mathrm{I}) \mathrm{R} 1 \mathrm{~A}$ followed by primers $\mathrm{rp}(\mathrm{II}) \mathrm{F} 2 / \mathrm{rp}(\mathrm{I}) \mathrm{R} 1 \mathrm{~A}$ (22). Amplified products were then digested with $T s p 509 \mathrm{I}$ and $A l u \mathrm{I}$ (Fermentas), and compared with reference phytoplasma strains from subgroups of the 16 SrII ribosomal group.

Sequencing and phylogenetic analysis. Further amplifications to obtain DNA for sequencing were performed on the L4 sample from $C$. arvensis using the $\mathrm{P} 1 / \mathrm{P} 7$ primer pair; the product from this reaction was amplified by nested PCR using the primers R16F2/R2. The conditions for direct and nested PCR were as follows: $95^{\circ} \mathrm{C}$ for $2 \mathrm{~min}, 96^{\circ} \mathrm{C}$ for $30 \mathrm{~s}, 50^{\circ} \mathrm{C}$ for 30 $\mathrm{s}, 72^{\circ} \mathrm{C}$ for $1.3 \mathrm{~min}$, and $72^{\circ} \mathrm{C}$ for $10 \mathrm{~min}$ for the last step, 35 cycles for the first PCR and 40 cycles for nested PCR. The 50- $\mu \mathrm{l}$ reaction mix contained $1 \times$ PCR buffer, 2 $\mathrm{mM} \mathrm{MgCl} 2,200 \mu \mathrm{M}$ each of the four dNTPs, $1 \mathrm{U}$ of Red Taq, $350 \mathrm{nM}$ of P1, $500 \mathrm{nM}$ of P7 for the direct PCR, and 500 $\mathrm{nM}$ of the R16F2/R2 primer pair for the nested PCR.

$\mathrm{R} 16 \mathrm{~F} 2 / \mathrm{R} 2$ amplified products $(1,256$ bp) were purified using a Qiagen PCR Purification Kit (Qiagen GmbH, Hilden, Germany, EU), and both strands were sequenced using R16F2 and R16R2 primers with an ABI Prism 377 Genetic Analyzer and the ABI Prism BigDye Terminator Cycle Sequencing Ready Reaction kit with AmpliTaq ${ }^{\circledR D N A}$ Polymerase (Perkin Elmer-Applied Biosystem, El Cajon, CA, USA). The gene sequence (about 1,164 bp) obtained in the Centro Ricerche Interdipartimentale Biotecnologie Innovative (CRIBI, Padua, Italy, EU) was deposited in the National Center for Biotechnology Information (NCBI, Bethesda, MD, USA) under accession no. AJ744767.

Partial sequences of the $16 \mathrm{~S}$ ribosomal gene from 32 representative strains of the genus "Candidatus Phytoplasma" (10) (Table 1), along with the above-described sequence from $C$. arvensis sample $\mathrm{L} 4(\mathrm{Ca}-$ lendula stunt), were aligned using the Clustal algorithm with Bioedit v.6.0.7. software (Tom Hall and Isis Pharmaceutical, Inc., Raleigh, NC, USA). Cladistic analyses were performed with Treecon

Table 2. Analysis of sequence similarities among 16SrRNA gene sequences from Calendula arvensis sample L4 (Calendula stunt) and nine phytoplasmas, the most of them belonging to 16SrII group

\begin{tabular}{|c|c|c|c|c|c|c|c|c|c|c|c|c|}
\hline Phytoplasma $^{a}$ & $\begin{array}{l}\text { 16SrRNA } \\
\text { subgroup }\end{array}$ & & 1 & 2 & 3 & 4 & 5 & 6 & 7 & 8 & 9 & 10 \\
\hline Calendula stunt & II-E & 1 & 100 & $\ldots$ & $\ldots$ & $\ldots$ & $\ldots$ & $\ldots$ & $\ldots$ & $\ldots$ & $\ldots$ & $\ldots$ \\
\hline PEP & n.a. ${ }^{b}$ & 2 & 99.38 & 100 & $\ldots$ & $\ldots$ & $\ldots$ & $\ldots$ & $\ldots$ & $\ldots$ & $\ldots$ & $\ldots$ \\
\hline ItalAWB & n.a. & 3 & 98.24 & 98.87 & 100 & $\ldots$ & $\ldots$ & $\ldots$ & $\ldots$ & $\ldots$ & $\ldots$ & $\ldots$ \\
\hline PapayaYC & II & 4 & 97.98 & 98.61 & 98.87 & 100 & $\ldots$ & $\ldots$ & $\ldots$ & $\ldots$ & $\ldots$ & $\ldots$ \\
\hline CPPW & II & 5 & 97.80 & 98.44 & 98.70 & 99.82 & 100 & $\ldots$ & $\ldots$ & $\ldots$ & $\ldots$ & $\ldots$ \\
\hline GP & n.a. & 6 & 97.63 & 98.27 & 98.53 & 99.65 & 99.48 & 100 & $\ldots$ & $\ldots$ & $\ldots$ & $\ldots$ \\
\hline LWB & II-B & 7 & 97.54 & 98.18 & 98.10 & 98.53 & 98.36 & 98.18 & 100 & $\ldots$ & $\ldots$ & $\ldots$ \\
\hline FBP & II-C & 8 & 97.45 & 98.10 & 98.18 & 98.44 & 98.27 & 98.10 & 98.81 & 100 & $\ldots$ & $\ldots$ \\
\hline Cactus & n.a. & 9 & 97.36 & 97.43 & 97.70 & 98.10 & 98.09 & 97.73 & 98.58 & 99.30 & 100 & $\ldots$ \\
\hline OmanAlfWB & II-D & 10 & 97.02 & 97.67 & 97.93 & 99.05 & 98.88 & 98.70 & 97.32 & 97.50 & 97.35 & 100 \\
\hline
\end{tabular}

a Phytoplasma abbreviations are explained in Table 1.

${ }^{\mathrm{b}}$ n.a. = group not available. 
version 1.3 B (Y. van de Peer, Konstanz, Germany, EU). A phylogenetic tree was constructed using the neighbor-joining criterion and visualized by Treecon. Acholeplasma palmae, a culturable Mollicutes, was designed as the out-group taxon to root the tree; bootstrap analysis was performed and replicated 1,000 times. To estimate the genetic relationships with the other phytoplasmas, considered as belonging to the same ribosomal group, the partial 16SrDNA sequence from sample Calendula stunt (L4) was compared with those of the following phytoplasmas: Oman Alfalfa witches'-broom, Chinese pigeon pea witches'-broom, Faba bean phyllody, Gerbera phyllody, Italian alfalfa witches'-broom, Lime witches'-broom, Papaya yellow crinkle, and Pichris echioides phyllody. The sequences were aligned using the BLAST engine for local alignment (version Blast $\mathrm{N}$ 2.2.10)
(NCBI), and percent identity was determined.

\section{RESULTS}

All weed samples produced no product in direct PCR with R16F2/R2 primers. The only samples yielding positive results after nested PCR with R16(I)F1/R1 primers were those collected in July. In particular, positive samples were: one of seven Chenopodium, three of six C. arvensis, and

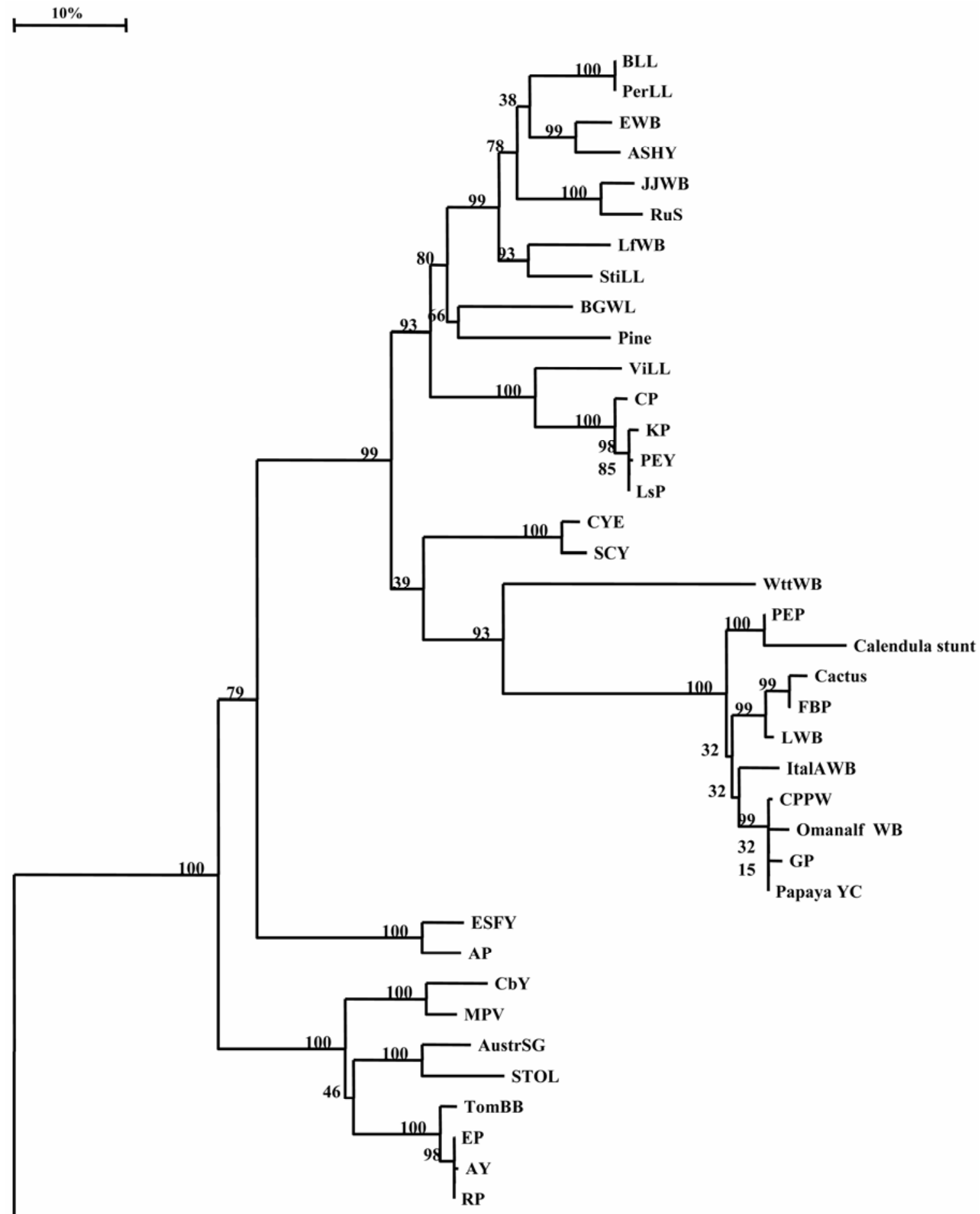

Acholeplasma palmae

Fig. 4. Phylogenetic tree constructed by parsimony analysis of 16SrRNA and spacer gene sequences from 38 phytoplasma taxa from GenBank. Numbers on branches of tree indicate bootstrap values. Acholeplasma palmae was employed as the out-group taxon. Abbreviations are given in Table 1. 
one of two $S$. nigrum. Based on RFLP analyses on R16(I)F1/R1 amplicons (Fig. 1 ), phytoplasmas from these weeds were assigned to the $16 \mathrm{SrII}$ ribosomal group (17). Further confirmation of these results was obtained after RFLP analysis on R16F2/R2 amplicons from the positive samples that produced banding patterns identical to each other and to those observed in the Picris echioides phyllody (PEP) phytoplasma control (Fig. 2). Moreover, sample Calendula stunt L4 showed an identical profile with the PEP phytoplasma after RFLP analyses of the S3 ribosomal protein gene (Fig. 3).

Comparison of the sequence obtained from the $C$. arvensis L4 sample showed higher and more significant homology (about 98\%) with some phytoplasmas: $99.38 \%$ identity with phytoplasma strain PEP from Southern Italy, $98.24 \%$ with Italian alfalfa witches'-broom (AlfWB), and 97.98\% with Papaya yellow crinkle (PapayaYC) from New Zealand (Table 2). Phylogenetic analysis confirmed that the Calendula stunt phytoplasma was closely related to Pichris echioides phyllody (PEP) (Fig. 4) and to all members of the $16 \mathrm{SrII}$ group.

The insects identified as most common in the vineyard were: Agallia ribauti Ossiannilsson with 10 adults captured in June, Empoasca vitis Göthe with 42 adults captured in August, Euscelis lineolatus Brullé with 57 adults and neanids captured in May, Laodelphax striatellus Fallén with 65 adults captured in June, and Psammotettix alienus Dahlbom with 20 adults captured in June. The tests carried out on samples of $A$. ribauti, E. lineolatus, $L$. striatellus, and $P$. alienus did not detect the Stolbur or any other 16SrII phytoplasmas. E. vitis samples were not analyzed.

\section{DISCUSSION}

In diseases caused by viruses or phytoplasmas, epidemiological studies are important, especially when there is a lack of such studies in a specific geographical area. The presence of unknown hosts and vectors in the epidemic process make it difficult to define the epidemiological framework. Phytoplasma infections in wild species, which act as intermediate hosts, have been reported $(2,23,24)$, and natural weed hosts specific for phytoplasma strains of subgroup 16SrXII-A have been described (20). We did not find Stolbur phytoplasmas in the wild species in the vineyard sampled in this study. This could indicate that secondary weed hosts were not present, but research was not exhaustive enough to confirm this hypothesis. By contrast, the identification of G. guttulinervis infected with 16SrXII-A in a vineyard insect population (5) leaves open the question of how the "Bois noir" disease is spread. No trophic relationships were found between this leafhopper and the plant species present in the vineyard sampled in this study.
Although epidemiological surveys done in a Chardonnay vineyard affected by "Bois noir" failed to detect 16SrXII-A phytoplasmas in weeds, three weed species, C. arvensis, S. nigrum, and Chenopodium spp., appear to be new hosts of 16SrII-E subgroup phytoplasmas. Our results confirm the suitability of R16F2/R2 primers for phytoplasma detection and the use of the group-specific primer pairs R16(I)F1/R1 for detection of 16SrII ribosomal group phytoplasmas (17). This is the first evidence that the R16(I)F1/R1 primers, in addition to amplifying phytoplasmas of ribosomal groups 16SrI and 16SrXII, can amplify phytoplasmas in all subgroups described within ribosomal group 16SrII (12) (Fig. 1). The molecular characterization of the gene coding the S3 ribosomal protein confirmed the identification of Calendula stunt phytoplasma, as well as indicated the possibility of using this gene to differentiate members of the 16SrII phytoplasma subgroup (22).

The Calendula stunt phytoplasma was 99.38\% similar to the PEP strain described in Southern Italy in Picris echioides based on the sequence of the $16 \mathrm{~S}$ gene (21). Finding genetically indistinguishable phytoplasmas in Sardinia indicates a wider distribution of 16SrII phytoplasmas, which until now have been reported in weeds and herbaceous crops in areas of Southern Europe $(21,27)$, Africa $(14,23)$, New Zealand (29), Asia $(24,25,30)$, Australia $(2,8,28)$, and America (19). In Oman, they were found in herbaceous and woody plants $(1,7,11)$ associated with severe losses of production; the leafhoppers Austragallia avicula Ribaut and Empoasca spp. were also described as potential carriers of the phytoplasma group 16SrII (13). In Mali, Orosius cellulosus Lindgerg was found to play an active role in transmitting 16SrII phytoplasma-associated phyllody from cotton plants and spontaneous mallows (Sida cordifolia and S. rhombifolia) (14).

Further investigations to verify the presence of leafhopper populations in the sampled vineyard showed a significant occurrence of $A$. ribauti and $E$. vitis during June and July 2003 (unpublished results); however, tests on both species for the presence of phytoplasmas gave negative results.

Soil management through no tillage, where possible, has gained increasing attention in viticulture. Implementation of this practice should be carefully evaluated in the environments where phytoplasma infections are spread, especially in the presence of alternative plant hosts and of possible arthropod vectors of phytoplasmas.

\section{LITERATURE CITED}

1. Al-Sakeiti, M. A., Al-Subhi, A. M., Al-Saady, N. A., and Deadman, M. L. 2005. First report of witches'-broom disease of Sesame (Sesamum indicum) in Oman. Plant Dis. 89:530.
2. Davis, R. I., Schneider, B., and Gibb, K. S. 1997. Detection and differentiation of phytoplasmas in Australia. Aust. J. Agric. Res. 48:535-544.

3. Deng, S., and Hiruki, C. 1991. Genetic relatedness between two nonculturable mycoplasmalike organisms revealed by nucleic acid hybridyzation and polymerase chain reaction. Phytopathology 81:1475-1479.

4. Doyle, J. J., and Doyle, J. L. 1990. Isolation of plants DNA from fresh tissue. Focus 12:3-15.

5. Garau, R., Sechi, A., Tolu, G., Prota, V. A. Lentini, A., and Prota, U. 2004. Goniagnathus guttulinervis (Kirschbaum) new natural host of the Stolbur subgroup 16SrXII-A phytoplasma in Sardinia. J. Plant Pathol. 86(2): 177.

6. Garau, R., Tolu, G., Prota, V. A., Sechi, A., Mungianu, M. P. M., and Prota, U. 2002. Osservazioni sul "Bois noir" della vite in Sardegna. Petria 12(3):445-446.

7. Garnier, M., Zreik, L., and Bové, J. M. 1991. Witches'-broom, a lethal mycoplasmal disease of lime trees in the Sultanate of Oman and the United Arab Emirates. Plant Dis. 75:546-551.

8. Gibb, K. S., Constable, F. E., Moran, J. R., and Padovan, A. C. 1999. Phytoplasmas in Australian grapevines - detection, differentiation and associated diseases. Vitis 38(3):107-114.

9. Gundersen, D. E., Lee, I.-M., Schaff, D. A., Harrison, N. A., Chang, C. J., Davis, R. E., and Kingsbury, D. T. 1996. Genomic diversity among phytoplasma strains in 16S rRNA Group I (Aster Yellows and related phytoplasmas) and III (X-Disease and related phytoplasmas). Int. J. Syst. Bacteriol. 46:64-75.

10. IRPCM Phytoplasma/Spiroplasma Working Team - Phytoplasma taxonomy group. 2004. Description of the genus 'Candidatus Phytoplasma', a taxon for the wall-less non-helical prokaryotes that colonize plant phloem and insects. Int. J. Syst. Evol. Microbiol. 54:12431255.

11. Khan, A. J., Azam, K. M., Deadman, M. L., Al-Subhi, A. M., and Jones, P. 2001. First report of alfalfa witches' broom disease in Oman caused by a phytoplasma of the $16 \mathrm{Sr}$ II group. Plant Dis. 85:1287.

12. Khan, A. J., Botti, S., Al-Subhi, A. M., Gundersen-Rindal, D. E., and Bertaccini, A. F 2002. Molecular identification of a new phytoplasma associated with alfalfa witches'-broom in Oman. Phytopathology 92:1038-1047.

13. Khan, A. J., Botti, S., Al-Subhi, A. M., Zaidi, M. A., Altosaar, I., Alma, A., and Bertaccini, A. 2003. Molecular characterization of the 16S-rRNA gene of phytoplasmas detected in two leafhopper species associated with alfalfa plants infected with witches' broom in Oman. Phytopathol. Mediterr. 42:257-267.

14. Laboucheix, J., Offeren, A. L., and van Desmidts, M. 1973. Étude de la transmission par Orosius cellulosus (Lindberg) (Homopt., Cicadellidae) de la virescence floreale du cotonnier et de Sida sp. Cotton Fibre Trop. 28(4):461-471.

15. Langer, M., Darimont, H., and Maixner, M. 2003. Characterization of isolates of Vergilbungskrankheit-phytoplasma by RFLPanalysis and their association with grapevine herbaceous host plants and vectors. Pages 6667 in: ICVG Conf., 14th, Locorotondo, (Bari) Italy; 2003 Sept. 12-17.

16. Langer, M., and Maixner, M. 2004. Molecular characterization of grapevine yellows associated phytoplasmas of the Stolbur-group based on RFLP-analysis of non-ribosomal DNA. Vitis 43:191-200.

17. Lee, I.-M., Gundersen, D. E., Davis, R. E., and Bartoszyk, I. M. 1998. Revised classification scheme of phytoplasmas based on RFLP analyses of $16 \mathrm{~S}$ rRNA and ribosomal protein gene sequences. Int. J. Syst. Bacteriol 48:1153-1169.

18. Lee, I.-M., Gundersen, D. E., Hammond, R. 
W., and Davis, R. E. 1994. Use of mycoplasmalike organism (MLO) group-specific oligonucleotide primers for nested-PCR assays to detect mixed-MLO infections in a single host plant. Phytopathology 84:559-566.

19. Leyva-López, N. E., Ochoa-Sánchez, J. C., Leal-Klevezas, D. S., and Martinez-Soriano, J. P. 2002. Multiple phytoplasmas associated with potato diseases in Mexico. Can. J. Microbiol. 48(2):1062-1068

20. Maixner, M., Ahrens, U., and Seemüller, E. 1995. Detection of the German grapevine yellows (Vergilbungskrankheit) MLO in grapevine, alternative hosts and a vector by a specific PCR procedure. Eur. J. Plant Pathol. 101:241-250

21. Marcone, C., Ragozzino, A., and Seemüller, E. 1997. Detection and identification of phytoplasmas in yellows-diseased weeds in Italy. Plant Pathol. 46:530-537.

22. Martini, M. 2004. Ribosomal protein genebased phylogeny: A basis for phytoplasma classification. Ph.D. thesis. University of Udine, Italy.
23. Saeed, E., Sarindu, N., Davies, D. L., Clark, M. F., Roux, J., and Cousin, M. T. 1994. Use of polyclonal antibodies to identify mycoplasmalike organisms (MLOs) from Sudan and from Thailand. J. Phytopathol. 142:345-349.

24. Schneider, B., Cousin, M. T., Klinkong, S., and Seemüller, E. 1995. Taxonomic relatedness and phylogenetic positions of phytoplasmas associated with diseases of faba bean, sun hemp, sesame, soybean and eggplant. Z. Pflanzenkr. Pflanzenschutz 102:225-232.

25. Schneider, B., Marcone, C., Kampmann, M., Ragozzino, A., Lederer, W., Cousin, M. T., and Seemüller, E. 1997. Characterization and classification of phytoplasmas from wild and cultivated plants by RFLP and sequence analysis of ribosomal DNA. Eur. J. Plant Pathol. 103:675686.

26. Schneider, B., Seemüller, E., Smart, C. D., and Kirkpatrick, B. C. 1995. Phylogenetic classification of plants pathogenic mycoplasma-like organisms or phytoplasmas. Pages 369-380 in: Molecular and Diagnostic Procedures in Mycoplasmology. Vol. 2. S. Razin and J. G. Tully, eds. Academic Press, New York.

27. Tessitori, M., Masenga, V., and Marzachi, C. 2005. First report of a phytoplasma associated with abnormal proliferation of cladodes in cactus pear (Opunzia ficus indica) in Italy. Plant Dis. Rep. 54:851-853.

28. Trau-Nguyon, L. T. T., Persley, D. M., and Gibb, K. S. 2003. First report of phytoplasma disease in capsicum, celery and chicory in Queesland, Australia. Aust. Plant Pathol. 32(4):5599-5600.

29. Waite, D. T., Blackall, L. L., Scott, P. T., and Walsh, K. B. 1998. Phylogenetic positions of phytoplasmas associated with dieback, yellow, crinkle and mosaic diseases of papaya, and their proposed inclusion in 'Candidatus Phytoplasma australasia'. Int. J. Syst. Bacteriol. 48:941-951.

30. Zreick, L., Carle, P., Bovè, J. M., and Garnier, M. 1995. Characterization of the mycoplasmalike organism associated with witches' broom disease of lime and proposition of a 'Candidatus Phytoplasma aurantifolia'. Int. J. Syst. Bacteriol. 45:449-453. 